„Śląskie Studia Polonistyczne" 2019, nr 2 (14) ISSN 2353-0928 (wersja elektroniczna)

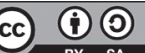

https://doi.org/10.31261/SSP.2019.14.15

\section{Karolina Kostyra}

UNIWERSYTET ŚLASKI W KATOWICACH

(iD https://orcid.org/0000-0002-4983-9195

Jak wyrwać się z nostalgii

Patrycja WŁodek: Kres niewinności. Obraz i upamiętnienie ery Eisenhowera w amerykańskich filmach i serialach - pomiędzy reprezentacją, nostalgią a krytycznym retro. Kraków: Wydawnictwo Naukowe Uniwersytetu Pedagogicznego, 2018, ss. 516.

Patrycja Włodek w książce Kres niewinności. Obrazi upamiętnienieery Eisenhowera $w$ amerykańskich filmach i serialach - pomiędzy reprezentacja, nostalgiq a krytycznym retro mierzy się z kolosem, jakim jest w kulturze amerykańskiej dekada lat pięćdziesiątych XX wieku. Z jej popularnością w hollywoodzkim kinie „nostalgicznym” równać mogą się jedynie współczesne filmowe i serialowe powroty do lat osiemdziesiątych. Autorka pisze, że w Stanach Zjednoczonych lata pięćdziesiąte rozpoczynają się zaraz po zakończeniu II wojny światowej, a kończą wraz z zabójstwem Johna F. Kennedy'ego, choć w kinie, czy w ogóle w kulturze popularnej, epoka białych przedmieść i rock and rolla nigdy być może nie dobiegła końca. Już początek lat siedemdziesiątych, gdy na ekranach pojawia się Amerykańskie graffiti (1973, reż. G. Lucas), zwiastuje kontynuację ery Eisenhowera. Natomiast Kształt wody (2017, reż. G. del Toro) i Green Book (2018, reż. P. Farrelly) jawią się jako najnowsze przedłużenia tego okresu. Choć autorka Kresu niewinności... nie miała już okazji wspomnieć w książce o zwycięskich oscarowych tytułach z dwóch ostatnich lat, to charakter dzieł Guillerma del Toro i Petera Farrelly'ego potwierdza poczynioną przez Włodek analizę tendencji obecnych w najnowszym kinie retro.

Książkę można potraktować jako uzupełnienie polskojęzycznej biblioteczki z kręgu estetycznych i filozoficznych refleksji nad reprezentacjami przeszłości (MARZEC, 2015; DRENDA, 2016; BAUMAN, 2018; REYNOLDS, 2018), a dla Włodek stanowi konsekwentną ścieżkę znaczoną redakcją publikacji Pomiędzy retro a retromaniq (MAJor, WEODEK, red., 2018) oraz tekstami z zakresu historii kina amerykańskiego. Dorobek filmoznawczyni z krakowskiego Uniwersytetu Pedagogicznego jest spójny i niezwykle bogaty; dla innych młodych akademików być może wręcz onieśmielający. $\mathrm{W}$ zasadzie sam pięciusetstronicowy Kres niewinności... mógłby stanowić materiał nie na jedną, ale dwie książki. Trzeba zaznaczyć już na wstępie, że najnow- 
sza praca Włodek dla miłośników amerykańskiej popkultury będzie prawdziwą perłą. Książka jest owocem oczytania w publikacjach filmoznawczych i wytężonej akademickiej pracy, choć pisana jest lekko, niczym dobrze skrojona powieść. Włodek ma wyróżniający się w polskim filmoznawstwie talent do omawiania kina w sposób świeży i zajmujący. Mając na uwadze, jak znakomitą pozycją jest Kres niewinności..., można zastanowić się nad ewentualnymi uzupełnieniami i polemicznymi propozycjami do wywodu autorki.

\section{Filmy nostalgiczne i kino kobiece}

W szerokim kontekście Kres niewinności... stanowi przedłużenie ponad czterdziestoletniej tradycji filmoznawczych badań związanych z amerykańskim kinem „nostalgicznym” (Le Sueur, 1977). Przedmiotem zainteresowania akademików z kręgu badań nad filmem nostalgicznym, kinem retro czy memory film (nomenklatura ulega zmianom w zależności od autorskiej orientacji piszącego) jest grupa filmów, które odtwarzają estetyczne style minionych dekad i powracają do wydarzeń historycznych w celu złagodzenia czy ukrycia dawnych napięć lub przeciwnie - przywrócenia sprawiedliwości dziejowej grupom poszkodowanym. Mimo żekino tego rodzaju często operuje strategiami wytwarzającymi poczucie zażyłości między widzem a oglądaną na ekranie wersją przeszłości, to ujawniającą się w tym kinie „nostalgię” najlepiej jest ująć w cudzysłów. Narodziny kina „nostalgicznego” nieprzypadkowo zbiegły się w czasie $\mathrm{z}$ powstaniem filmowego postmodernizmu zakorzenionego programowo w chwytach dystansujących.

Realizacje z kręgu kina „nostalgicznego" nierzadko usiłują wywołać iluzję „przypominania” odbiorcom, jak było kiedyś, odwołując się do powszechnie kojarzonych z daną epoką elementów - standardów muzyki rozrywkowej, ikonicznej scenografii i kostiumów, specyficznej kolorystyki, konkretnych rodzajów postaci i gatunków filmowych. Przykładowo, w opowieści o amerykańskich latach pięćdziesiątych mogą pojawić się takie symbole epoki, jak przebój Rock Around the Clock, restauracje typu diner, rozkloszowane spódnice, technikolorowe lub pastelowe barwy kadrów, a gatunkowo film odtwarzający erę Eisenhowera będzie wpisywać się w melodramat lub kino młodzieżowe $\mathrm{z}$ typowymi dla tych konwencji postaciami (znerwicowana pani domu albo nastoletni buntownik na motorze). Treść wspomnień, które podsuwane są widzowi przez film „nostalgiczny", uwarunkowana jest oczywiście orientacją ideologiczną teraźniejszości, co we współczesnych studiach nad kinem opowiadającym o przeszłości przyjmowane jest za punkt wyjścia. Stwierdzenie, że przeszłość produkowana jest przez teraźniejszość, to już właściwie banał - pisała w kontekście memory films Pam Cook (2005, 
s. 19). Nie oznacza to jednak, że kino odtwarzające minione czasy traktowane jest przez analityków jedynie jako narzędzie służące celom dominującej polityki.

Już w latach osiemdziesiątych Fredric Jameson krytykował nostalgia film za fałszywy sposób, w jaki to „wizualne kuriozum” reprezentuje przeszłość (JAMESON, 1984), ale po serii interwencji feministycznych na przełomie lat osiemdziesiątych i dziewięćdziesiątych (CREed, 1987, s. 53; Hutcheon, 1998) - i ukazaniu się wpływowej, również na gruncie medioznawstwa, publikacji Swietłany Bojm The Future of Nostalgia (BoJM, 2002) - najnowsze badania koncentrują się często na progresywnym potencjale tkwiącym w kinie opowiadającym o minionych dekadach. Analizy Cook, Włodek i innych filmoznawczyń zainteresowanych kwestią kina traktującego o przeszłości łączy przeświadczenie, że nie każdy film „nostalgiczny” jest z gruntu konserwatywny. We wstępie do zbioru esejów Cook na temat przeszłości, pamięci i nostalgii w kinie czytamy, że nostalgia (a tym samym kino „nostalgiczne”) nie musi być odbierana jako kategoria naznaczona wstecznym, ckliwym czy fałszywym podejściem do przeszłości, lecz może służyć za formę egzorcyzmu - zabiegu, który pozwala wywołać, przepracować i pożegnać w lepszej atmosferze niepokoje dawnych czasów (Cook, 2005, s. 3). Również Christine Sprengler w swoim omówieniu stylu wizualnego współczesnych amerykańskich produkcji osadzonych w latach czterdziestych i pięćdziesiątych zaznacza, że zależy jej na tym, aby odnaleźć „krytyczny potencjał" nawet w tych nostalgicznych realizacjach, które na pozór mogą wydawać się śmieszne i błahe (SPRENGLER, 2009, s.3). Z kolei Włodek w Kresie niewinności... zajmuje się między innymi analizą filmów, które wpisuje w kategorię o symptomatycznej nazwie „krytyczne retro”.

Zarówno polska filmoznawczyni, jak i anglosaskie akademiczki zainteresowane są melodramatami, filmami obyczajowymi i komediami romantycznymi, a więc produkcjami, które w potocznym widzowskim osądzie łączone są z „kinem kobiecym” (woman’s film lub chick flick). Filmy o kobietach i/lub operujące kobiecą perspektywą i oglądane najchętniej przez kobiety uznawane były w większej części historii kina za mało szlachetne, bo skupione przede wszystkim na kwestiach prywatnych. Dodatkowo przedmiotem pracy Włodekjest film młodzieżowy - gatunek cieszący się jeszcze mniejszym uznaniem niż „kino kobiece”. Kres niewinności... wpisuje się tym samym w nurt feministycznie zorientowanych badań filmoznawczych, które skupione są na „odzyskiwaniu” produkcji do niedawna jeszcze negatywnie wartościowanych przez dużą część publiczności

1 Filmowe „krytyczne retro” w artykule Nie tylko nostalgia. Fenomen retro krytycznego omawia także Barbara SzczekA£A (2018, s. 255-280). 
i krytyki filmowej. Krakowska akademiczka nie rehabilituje w swojej pracy nostalgicznego retro reaganizmu, choć już o kanonicznym dla kina spod znaku wstydliwej przyjemności filmie Dirty Dancing (1987, reż. E. Ardolino) pisze, że to jedynie pozornie konserwatywna realizacja, w której nostalgiczna słodycz służy za „zasłonę dymną dla wątków właściwych, czyli transgresji Baby oraz aborcji” (s. 320). Wydaje się, że kinowe rewizje i nostalgiczne powroty do amerykańskich lat pięćdziesiątych są idealnym terenem do diagnozowania tego, co kryje się za podobną zasłoną dymną.

\section{Lata pięćdziesiąte}

\section{i lata pięćdziesiąte trzy dekady później}

Strategia wyboru konkretnych przykładów kina "nostalgicznego", jakie autorka przytacza w książce, prowadzona jest z uwzględnieniem dalekich marginesów list popularnych tytułów i sztandarowych arcydzieł. Włodek poświęca sporo uwagi ikonicznym dla danych epok dziełom, jak Buntownik bez powodu (1955, reż. N. Ray), Powrót do przysztości (1985, reż. R. Zemeckis) czy Daleko od nieba (2002, reż. T. Haynes), w rozdziałach historycznych natomiast wywód wzbogaca o odniesienia do tytułów charakterystycznych dla swych czasów, choć umiarkowanie prestiżowych w momencie powstania, obecnie zaś zupełnie zapomnianych. Tyczy się to szczególnie części książki o kinie lat pięćdziesiątych, w której omówione są zarówno wspomniane melodramaty, jak i filmy rockandrollowe oraz produkcje klasy B, a także - obok Elvisa Presleya, Jamesa Deana i Marilyn Monroe - takie postacie, jak Sandra Dee, Jayne Mansfield i Pat Boone, których nazwiska kojarzone są teraz głównie przez koneserów kultury vintage. W literaturze przedmiotu autorka znajduje błyskotliwe terminy dla podgatunków charakterystycznych dla dekady Eisenhowera, jak delayed fuck movie, odnoszący się do konserwatywnych romantycznych sekskomedii, w których o seksie mówiło się sporo, ale stosunek dozwolony był dopiero w finale, gdy para zdecydowała się w końcu na małżeństwo. Włodek dostrzega niuanse i mikronuty, ale jednocześnie z rozmysłem unika pisania o najistotniejszych dla tego okresu gatunkach, takich jak western, science fiction, horror i peplum. Swoją uwagę koncentruje przede wszystkim na kinie opowiadającym o przedmieściach, licealnych korytarzach, biurach korporacji oraz, w mniejszym stopniu, na przestrzeniach znaczonych przez kameralne kino biograficzne.

Pięciusetstronicowa książka jest nadzwyczaj spójna. Autorka regularnie powraca do tematów związanych z odrębnością stylu życia nastolatków, satysfakcją lub rozczarowaniem dorosłych w sferze domowej i zawodowej oraz marginalizacją grup mniejszościowych (głównie kobiet i Afroamerykanów). Choć badaczka musiała opra- 
cować spory fragment historii kina i zobligowana była do nakreślenia tendencji esencjalnych dla współczesnych produkcji retro (w tym wypadku również analizy neoseriali, w której notabene Włodek się specjalizuje), to wywód autorki Kresu niewinności... ani nie ulega dygresyjnemu rozproszeniu, ani nie popada w monotonię. Książka oczarowuje harmonią narracyjną, która jest niezwykle trudna do uzyskania w przypadku publikacji z zakresu historii kina (szczególnie tych z obszerną filmografią). To publikacja imponująca, lecz elegancka - estetycznie bliska przedmiotowi swoich badań.

Z pierwszych podrozdziałów książki wynika, że lata pięćdziesiąte same w sobie były filmowe. W rzeczywistości i wyobrażeniach popkulturowych tego okresu, jak zauważa Włodek, „wszystko było większe, lepsze, bardziej ostentacyjne, wręcz rozbuchane" (s. 31). Styl kolorowej ilustracji reklamowej, kobieca moda, w której liczyła się wykwintna, ale wyrazista forma (szpiczaste, torpedowe staniki, talie ściągnięte pasem wyszczuplającym, usztywniane spódnice), a nawet seksapil minimalistycznego stroju bitników i rockersów, tworzą dla tej dekady prawie komiksową estetykę, kod wizualny, który przez filmowców „nostalgików” wykorzystywany jest w formie wabika plastycznego. Czasem, powiedzmy w twórczości Todda Haynesa, stylizacja retro idzie w parze ze spojrzeniem z ukosa na epokę Eisenhowera, innym razem lata pięćdziesiąte zostają sprowadzone do tak zwanych fiftiesów - dostarczają pretekstu do eskapistycznej zabawy w starym stylu, czego przykładem jest Grease (1978, reż. R. Kleiser). Być może urok wizualny tej powtórzonej dekady zmusza analityków do szukania treści, które mogą się skrywać pod efektowną powierzchnią mise-en-scène. Mówiąc inaczej, piękne kino opowiadające o przeszłości często wydaje się podejrzane pod względem politycznym. Również w badaniach Włodek kluczową kwestią jest identyfikacja ideologiczna konkretnych przykładów filmowych, a ostatecznie całych epok z historii kinematografii amerykańskiej.

Polska filmoznawczyni, inaczej niż Sprengler, Cook i pozostałe akademiczki nieodmawiające nostalgii potencjału krytycznego (NIEMEYER, ed., 2014, s. 2), w pisaniu o progresywnych filmach o przeszłości preferuje kategorię retro. W stanowisku Włodek nostalgia diagnozowana jest jako „idealizując[a] tęsknot[a] - zjawisko z obszaru psychologii” (s. 255), czyli raczej nostalgia modernistyczna - nostalgia pozbawiona cudzysłowu. Retro lokuje się natomiast w obszarze estetyki i oparte jest na „samoświadomych odwołaniach stylistycznych do relatywnie nieodległej przeszłości” (s. 256).

Włodek wprowadza rozróżnienie na retro nostalgiczne (afirmujące przeszłość) oraz retro krytyczne (związane z demitologizowaniem minionych czasów). Ten ścisły terminologiczny podział przekłada się na periodyzację historii kina, w której filmy epoki 
reaganizmu związane są z konserwatywną nostalgizacją eisenhowerowskiej przeszłości (czyli retro nostalgicznym), najnowsze produkcje serialowe i filmowe zaś wpisują się w obręb krytycznego retro. Krytyczne retro reprezentowane między innymi przez Godziny (2002, reż. S. Daldry), Daleko od nieba oraz seriale Mad Men (2007-2015) i Masters of Sex (2013-2016) jest dla badaczki zjawiskiem „dokładnie przeciwnym” reaganomatografii idealizującej lata pięćdziesiąte (s. 255).

Na pierwszy rzut oka poczynione przez Włodek rozróżnienie historyczne wydaje się oczywiste. „Retro zawsze jest [...] konserwatywne światopoglądowo”, pisał niedawno w kontekście „reaganomatoretro" Rafał Syska (2012, s. 15). Włodek, choć nie zgodziłaby się z Syską co do konserwatywnego charakteru wszystkich retro przedstawień, również odmawia progresywnego potencjału kinu epoki Reagana. Syska i Włodek nie są odosobnieni w tym stanowisku. Głównonurtowe amerykańskie kino lat osiemdziesiątych zarówno w publicystyce, jak i na gruncie akademickim czytane jest jako wielka konserwatywna machina - przejaw perfekcyjnej symbiozy polityki Ronalda Reagana z wizją ideologiczną przedstawianą w hollywoodzkich produkcjach. Jednym z elementów działania tej machiny była właśnie nostalgiczna gloryfikacja lat pięćdziesiątych ujmowanych jako dekada niewinności, świeżości, dobrobytu. Nie miało znaczenia, jak swoją orientację polityczną określali reżyserzy nostalgicznego retro. Kevin SMOKLER (2016, s. 154) w omówieniu Stań przy mnie (1986, reż. R. Reiner), Powrotu do przyszłości i Peggy Sue wyszła za maż (1986, reż. F.F. Coppola) zauważa, że twórcy tych filmów identyfikowali się zawsze jako demokraci, którzy wiele zawdzięczają dziedzictwu lat sześćdziesiątych. W latach osiemdziesiątych jednak wszyscy trzej woleli pokazywać bezpieczną erę Eisenhowera. Bezpieczną, bo ten okres w przedstawieniach z Footloose (1984, reż.H. Ross) czy właśnie Powrotu do przyszłości zostaje wykastrowany z autentycznych kontrkulturowych impulsów, pozbawiony bolesnej historii, sprowadzony do garści sympatycznych popkulturowych stereotypów, nad czym ubolewał już Jameson w słynnych krytykach nostalgia film. Nie sposób nie zgodzić się z autorką Kresu niewinności..., gdy diagnozuje ona retro lat osiemdziesiątych jako wyraz zawłaszczenia buntu. Zdaniem Włodek, świat nostalgicznego retro zaludniają „fałszywi buntownicy”, których protest sprowadza się do noszenia obowiązkowej skórzanej kurtki i kilku pozerskich dąsów.

\section{Dziewczyny w stylu retro}

Może jednak badaczka zbyt surowo potraktowała kino lat pięćdziesiątych? W rozdziale Czas zatrzymany - lata osiemdziesiąte pogląd, 
że retro lat osiemdzisiątych miało charakter wsteczny lub właśnie „wstrzymujący”, jest przełamany w zasadzie tylko subwersywną lekturą Dirty Dancing jako kina prokobiecego. Włodek zauważa odmienność modelu retro proponowanego w tym czasie przez Johna Watersa, ale nietypowość Lakieru do włosów (1988) i Beksy (1990) sprowadza tylko $i$ aż do specyficznego stylu ich autora oraz ironicznego, wyprzedzającego epokę, komentarza na temat popkulturowej fetyszyzacji ery rock and rolla. W tym wypadku należałoby raczej przyznać rację Smoklerowi, który stwierdza, że obydwie realizacje „Sięgają po niewinność ery, którą Ronald Reagan pragnął wskrzesić po to, by przepisać ją jako zaściankową i bigoteryjną" (SMOKLER, 2016, s. 166, tłum. - K.K.). Nie chodzi tylko o to, że w Lakierze do włosów przedstawiono międzyrasowy związek (również erotyczny) nastolatków z uprzedzonego w tym okresie do czarnoskórych Baltimore. Co równie istotne, a o czym Włodek nie wspomina wprost, w obydwu filmach casting godzi w kanoniczne wzorce kobiecej urody. W Beksie wygląd pary głównych bohaterów (odgrywanych przez uosobienie chłopięcego uroku Johnny'ego Deppa i obdarzoną porcelanową urodą Amy Locane) kontrastuje z aparycją członkiń gangu Beksy - groteskowo wykrzywioną twarzą Kim McGuire i pulchną figurą Ricki Lake. W Lakierze do włosów Lake została przez Watersa obsadzona w głównej roli. Jest nastoletnią tancerką postacią na pewno nie mniej sprawczą niż Baby z Dirty Dancing, a przy okazji o urodzie zupełnie nieprzystającej do wzoru uosabianego przez drobniutką miłośniczkę mambo z amerykańskiego hitu. Fizyczność postaci kreowanej przez Lake nie zostaje poddana normalizowaniu (makijaż i kostiumy wręcz uwydatniają duży rozmiar aktorki i jej przeciętną w kanonach twarz), co jest nietypowe dla przedstawień pierwszoplanowej postaci kobiecej w kinie retro. W późniejszym krytycznym retro (o którym Włodek pisze w kontekstach feministycznych) na próżno szukać pierwszoplanowych bohaterek o wyglądzie tak mocno godzącym w kanon hollywoodzkiej urody. W latach pięćdziesiątych XX wieku wszystkie kobiety wyglądają zjawiskowo.

Nie da się jednak ukryć, że Lake w latach osiemdziesiątych stanowi wyjątek, jeśli chodzi o typ fizyczności, jak i sprawczość, jaką obdarza postać odgrywaną przez tę aktorkę reżyser. Autorka książki wspomina o roli kobiet między innymi w kontekście Diner (1982). Ten buddy film Barry'ego Levinsona w tonacji ciepłej nostalgii przedstawia motyw ukrywania penisa w pudełku na popcorn tak, aby cnotliwa partnerka jednego $\mathrm{z}$ bohaterów dotknęła jego członka w przeświadczeniu, że sięga po prażoną kukurydzę. W erze Reagana kino retro wypełnione jest podobnymi pudełkami z „kukurydzą". Aby uzupełnić wywód Włodek, można dodać, że o tym, jak „nostalgiczne” kino lat osiemdziesiątych traktowało dziewczęce bo- 
haterki, najlepiej świadczą sekskomedie dla nastolatków. W kanonicznym młodzieżowym filmie Świntuch (1981, reż. B. Clark) atrybutami młodych kobiet są przede wszystkim zwilżone wodą z prysznica biusty podglądane przez chłopięcych bohaterów. W „nostalgii masturbacyjnej" (MCPADDEN, 2019, s. 208) lata pięćdziesiąte ujmowane są jako raj dla dorastających mężczyzn - pole do nieograniczonych wojerystycznych seansów i nerwowych prób obłapiania koleżanek w takt starych przebojów. Choć w filmach o znamiennych tytułach, jak Figiel (1985, reż. M. Damski) czy Tracącto (1983, reż.C. Hanson) trudno dostrzec równościowe podejście do seksualności dziewcząt i chłopców, to warto zauważyć, że nostalgiczne retro (wraz ze swoją konserwatywną wymową) było niezwykle śmiałe w obrazowaniu cielesności. Reaganomatografia dopowiadała to, co w kinie sprzed trzydziestu lat, często bardziej zmysłowym, ale z oczywistych względów wizualnie zachowawczym, nie mogło się w pełni zamanifestować. Nawet w tak skandalizujących niegdyś opowieściach o nastoletniej seksualności, jak A Summer Place (1959, reż. D. Daves), Peyton Place (1957, reż. M. Robson) i Wiosenna bujność traw (1961, reż. E. Kazan) erotykę raczej się sugeruje, niż pokazuje. Zatem z jednej strony młodzieżowe sekskomedie lat osiemdziesiątych jawią się jako przykłady mało wyszukanej seksistowskiej „nostalgii masturbacyjnej”, z drugiej oferują pewną formę „wypełnienia luk" dawnego kina (nawet jeśli w tym wypadku innowacja przybiera formę biustu podglądanego przez dziurkę od klucza).

W kontekście analizowanego przez Włodek Dirty Dancing nie sposób zignorować innych filmów inicjacyjnych, które wyłamywały się z wzorca bezrefleksyjnej nostalgii za epoką Eisenhowera. Być może najbardziej progresywnym gatunkiem w okresie retro nostalgicznego był - wydawałoby się, z gruntu konserwatywny i nostalgiczny - film o dorastaniu. Twórcy Ode to Billy Joe (1976, reż. M. Baer Jr.) i Człowieka z księżyca (1990, reż. R. Mulligan) za miejsce akcji obrali nie przedmieścia, ale głęboką prowincję lat pięćdziesiątych, na której młodzi bohaterowie poznawali seksualność (również kobiecą i nieheteronormatywną) i stykali się ze śmiercią bliskich. Warto zauważyć, że w tym samym roku, w którym na ekranach ukazało się czarujące Amerykańskie graffiti, widzowie mieli także okazję obejrzeć Badlands (1973) Terrencéa Malicka, w którym młodziutka mieszkanka suburbiów epoki Eisenhowera, wraz ze stylizowanym na Jamesa Deana chłopakiem, zabija wyznającego tradycyjne zasady ojca i pali swój piękny swój piękny rodzinny dom na przedmieściach. Para ucieka z obrzeży miasta w kierunku tytułowych „złych ziem”. W mit cudownych amerykańskich lat pięćdziesiątych najbardziej ugodzi jednak Out of the Blue (1980) - produkcja stworzona w Kanadzie, ale wyreżyserowana przez ultraamerykańskiego twórcę Denisa Hoppera. Hopper w myśl opisującego kres rock and rolla utworu 
Neila Younga $M y M y$, Hey Hey (Out of the Blue) da do zrozumienia, że lepiej doszczętnie spalić przeszłość, niż patrzeć, jak blednie.

\section{Nimfetki i bumelanci}

Kino lat osiemdziesiątych bardzo dosadnie „wypełniało luki” przedstawień sprzed trzech dekad. W epoce Reagana jednym z najpopularniejszych gatunków był film akcji, który może być czytany, jak proponuje Włodek, przede wszystkim jako przejaw kultury agresywnego maczyzmu. Zarazem jednak reaganowski action film uwidacznia bohaterów wcześniej marginalizowanych. Poprzez protagonistów ucieleśnianych przez Sylvestra Stallone’a i Arnolda Schwarzeneggera uwznioślona zostaje postać mężczyzny z klasy ludowej - w kinie epoki Eisenhowera spychana na boczne tory, bo niepasująca do wizji burżuazyjnych przedmieść. Kino reaganizmu obdarzyło mężczyzn z klasy ludowej sprawczością, być może nawet zbyt potężną i gwałtowną, bo ostatecznie umięśnieni bohaterowie rzeczywiście realizują wzorzec „męskości barbarzyńskiej”, jak nazywa ten typ roli autorka książki. Co prawda, w latach pięćdziesiątych męskość proletariacka i podklasowa była seksualizowana, między innymi w adaptacjach sztuk Tennessee Williamsa i filmach o wykolejonej młodzieży, ale postulowanym wzorem był, jak pisze Włodek, dobry mąż i korporacyjny pracownik - nie spocony Stanley Kowalski, ale człowiek w szarym flanelowym garniturze. Autorka Kresu niewinności... twierdzi zresztą, że seksapil Marlona Brando, Jamesa Deana, Paula Newmana i Montgomery'ego Clifta można utożsamiać raczej z chłopięcym urokiem (na który składa się wraźliwość emocjonalna i fizyczne piękno) niż z wzorami kojarzonymi z konwencjonalną męskością. Na marginesie spostrzeżeń badaczki warto zauważyć, że spośród mężczyzn-chłopców szczególnie Brando w Tramwaju zwanym pożądaniem (1951, reż. E. Kazan) stworzył ikoniczną dla proletariackiego seksapilu postać umięśnionego "chama” w brudnym podkoszulku. W subkulturowym klasyku Dziki (1953, reż. L. Benedek) ukazany został zbliżony typ bohatera kreowanego przez Brando w bardziej romantycznej odsłonie, sparowany z niewinną młodą kobietą. Szczegóły tego romansu są intrygujące z punktu widzenia kobiecej seksualnej samoświadomości w kinie lat pięćdziesiątych. W jednej ze scen „czysta dziewczyna” z klasy średniej komentowała rozkosz, jaką dała jej inicjacyjna motocyklowa przejadżka ze społecznym wyrzutkiem. Po zmysłowej jeździe rozmarzona bohaterka wodziła dłonią po maszynie i zwierzała się partnerowi: „Nigdy wcześniej nie jechałam na motocyklu. To tak szybko... Bałam się... Ale o wszystkim zapomniałam. Tak mi było dobrze". Młoda kobieta po tych słowach wtuliła twarz 
w zawieszenie motocykla, a postać odgrywana przez Brando na moment straciła rezon.

W kinie lat pięćdziesiątych konwencja fantazji erotycznej, w jakiej partnerką wspaniale zbudowanego mężczyzny z klasy ludowej (często włóczęgi) jest dorastająca dziewczyna, której wiek i niewielkie doświadczenie podkreślane są przez słodycz wizerunku (blond włosy i różowe stroje), pojawi się w filmach Piknik (1955, reż.J. Logan) oraz Gidget (1959, reż. P. Wendkos). Ten drugi funkcjonuje w historii kina jako przykład zupełnie niewinnego filmu młodzieżowego - opowieść o grzecznej nastolatce w typie określanym przez Włodek jako clean teen. Autorka wspomina o emploi Sandry Dee i konserwatywnej wymowie historii (która, jak zaznacza, ma mimo wszystko pewien potencjał związany z kobiecą emancypacją przez sport). Rzeczywiście, w warstwie fabularnej czystość tytułowej nastolatki zostaje zachowana, a ona sama wybiera w finale chłopca z dobrego domu. Jednak w kreowanych przez twórców wizjach nagminnie proponowane są obrazy o naturze raczej „włochatej” niż „czystej”. Niziutka, infantylna nastolatka (mentalnie i wizualnie typ nimfetki) stale otoczona jest półnagimi starszymi od siebie mężczyznami. Urocza dziewczyna-karzełek (surferzy nazywają ją Gidget - od girl i midget) jest o krok od utraty dziewictwa z plażowym bumelantem z niższej klasy społecznej i chociaż logika fabularna i cenzura kinowa skrzętnie chroniły czystość grzecznej blondynki, to sugestia złamania klasowego tabu została zasiana.

W latach osiemdziesiątych inkarnacje konwencji parującej nastolatkę w typie clean teen ze średniej lub z wyższej klasy z męskim czy chłopięcym wyrzutkiem z klasy ludowej znajdziemy nie tylko we wspomnianym Dirty Dancing, lecz także w romansach młodzieżowych Ogień z ogniem (1986, reż. D. Gibbins) i Buntownik z Eberton (1984, reż. J. Foley) - filmach nierozgrywających się w epoce Eisenhowera, ale takich, w których operowano kodami wizualnymi lat pięćdziesiątych (skórzana kurtka, biały T-shirt, motocykl, „kogucia" fryzura) ${ }^{2}$, a konstrukcja psychologiczna męskiego bohatera była podobna - mężczyzna kreowany był na strong, silenttype. Ciekawe, że w kinie Obamy postaci tajemniczych silnych proletariuszy wydają się nieobecne, ustępują miejsca inteligentnym czarnym pracownicom z analizowanych przez Włodek filmów Służące (2011, reż. T. Taylor) i Ukryte działania (2016, reż. T. Melfi).

2 W tym czasie najważniejszym chłopięcym potomkiem proletariackiej Ameryki lat pięćdziesiątych będzie jednak Bruce Springsteen, postać spoza świata filmu. W odsłonie kobiecej rolę „fiftiesowej” nastolatki z niższej klasy przyjmie Madonna z czasów jej albumu True Blue. 


\section{Czy krytyczne retro jest krytyczne?}

W zakresie wątków związanych z klasą społeczną książka Kres niewinności... może pozostawiać niedosyt. Jest on o tyle odczuwalny, że filmoznawczyni z Uniwersytetu Pedagogicznego dogłębnie opisuje przecież na przykład niuanse związane z płcią, rasą, grupą wiekową i orientacją seksualną, a przy tym jest czuła na ich kinowe reprezentacje i wykluczenia. Czasem, jak w przypadku opisu pozycji klasowej ogrodnika z dzieła Douglasa Sirka Wszystko, na co niebo zezwala (1955), „nieco niegorzej sytuowany (co nie znaczy, że biedny), z innej warstwy społecznej" (s. 208) czytelnik może zapragnąć mocniejszych słów. Kwestie klasowe pojawiają się oczywiście w książce można wręcz powiedzieć, że większa część badań Włodek nad kinem lat pięćdziesiątych i odbiciami tej dekady w późniejszych filmach skoncentrowana jest na tropieniu „skutków ubocznych” dominacji białych przedmieść. Autorka notuje przy tym obecne w filmach i serialach klasowe reprezentacje, ale przeważnie przytacza je przy okazji omawiania tematów związanych z płcią i rasą, co po części jest wypadkową charakteru kina hollywoodzkiego. Tematem współczesnego amerykańskiego kina głównego nurtu mogą być wykluczenia ze względu na rasę, płeć, pochodzenie etniczne, orientację seksualną i stan zdrowia. Wątki klasowe realizowane są natomiast raczej przy okazji, a przecież - jak przekonuje rewizyjny dokument Little Rock: Pót wieku później (2007, reż. B. Renaud) podziały klasowe są współczesną formą rasizmu.

W tym sensie ostrze krytyki społecznej w filmach Służące i Ukryte działania wydaje się stępione. Umiejscowieniem akcji w przeszłości twórcy niejako oddalają realne wykluczenia do bezpiecznej sfery dawnych czasów. Uprzedzenia klasowe standardowo łączone są z rasizmem przedstawionym w formule, która została już przecież przepracowana przez liberalne narracje (w tym kino głównego nurtu). Opowieści o czarnych pracownicach i stworzony $\mathrm{w}$ innej tonacji, choć tematycznie nieodległy Kamerdyner (2013, reż. L. Daniels) wydają się bezpieczne w swoim liberalnym antyrasizmie. Ukryte działania są wręcz produkcją wsteczną, jeśli weźmiemy pod uwagę fakt, że jedna $\mathrm{z}$ bohaterek filmu (Katherine) nie ma w zasadzie cech osobowych, za to stale zadziwia swoją inteligencją białych bohaterów (co przedstawia kobietę jako wcielenie rasistowskiego schematu Magical Negro). Kino epoki Obamy omawiane jest przez autorkę Kresu niewinności... w tonie afirmatywnym, choć, co należy zaznaczyć, w żadnym wypadku niebezkrytycznym. Zastanawia jednak, w jakim stopniu najnowsze produkcje faktycznie różnią się od przeciwstawianych im przez Włodek konserwatywnych filmów doby Reagana. Nie sposób oczywiście kwestionować tego, że we współczesnych realizacjach proponuje się niepochlebny model spojrzenia na erę Eisenhowera (szczególnie jeśli porównać je z zaba- 
wową odsłoną nostalgicznego retro lat osiemdziesiątych). Wydaje się jednak, że krytyczne retro często wyważa otwarte już drzwi.

Gdy zestawimy konkurujące o Nagrodę Akademii Ukryte działania $\mathrm{z}$ uhonorowanym główną statuetką Moonlight (2016, reż. B. Jenkins), będziemy mogli zauważyć, jak bardzo ten pierwszy film zasklepiony jest w sztampowych hollywoodzkich konwencjach ideologicznych, estetycznych i narracyjnych. Twórcy krytycznego retro z pewnością nie patrzą na przeszłość przez różowe okulary, ale nie oznacza to, że jako twórcy kina swoich czasów trzymają rękę na pulsie. O tym, że krytyczne retro zjada własny ogon (albo nigdy nie było w pełni krytyczne), świadczy Green Book - oscarowy zwycięzca z 2018 roku. Osadzona w 1962 roku opowieść, owszem, ukazuje rasowe, klasowe i seksualne uprzedzenia swej epoki, ale zarazem przekonuje widza, że rasa, klasa i orientacja seksualna są tylko pozornymi barierami, a przy odrobinie dobrej woli (a nie dzięki systemowym zmianom) przeszłość i przyszłość staną się gościnne. Dodatkowo, w filmie Farrelly'ego afroamerykański bohater jest jeszcze mniej ludzki niż Katherine z Ukrytych działań. Bardziej zniuansowanym przykładem krytycznego retro okazuje się Kształt wody opisujący „potworny” dla systemu sojusz wykluczonych społecznie reprezentantów mniejszości.

Można się zastanawiać, czy krytyczne retro w swojej pokrzepiającej odsłonie nie zbliża się do idealizujących wizji przeszłości, które (jak w latach osiemdziesiątych) mają jedynie umacniać status quo. Czy we współcześnie odtwarzanych na ekranie latach pięćdziesiątych motyw społecznego wykluczenia nie staje się równie oczywistym dla filmu „nostalgicznego” elementem jak rozkloszowana spódnica, wnętrza restauracji diner i przebój Rock Around the Clock?

\section{Bibliografia}

Bauman Zygmunt, 2018: Retrotopia. Jak rządzi nami przeszłość. Przeł. Karolina LeBEK. Warszawa: Wydawnictwo Naukowe PWN.

BoJM Swietłana, 2012: The Future of Nostalgia. New York: Basic Books.

Cook Pam, 2005: Screening the Past: Memory and Nostalgia in Cinema. New York: Routledge.

CReEd Barbara, 1987: From Here to Modernity: Feminism and Postmodernism. „Screen”, vol. 28.

DRENDA Olga, 2016: Duchologia polska: rzeczy i ludzie $w$ latach transformacji. Kraków: Karakter.

Hutcheon Linda, 1998: Irony, Nostalgia, and the Postmodern. [Online:] https://web.archive.org/web/20050317095114/http://www.library. utoronto.ca/utel/criticism/hutchinp.html [1.07.2019]. 
Jameson Fredric, 1984: Postmodernism, or the Cultural Logic of Late Capitalism. „New Left Review”, vol. I/146. [Online:] https://newleftreview. org/issues/I146/articles/fredric-jameson-postmodernism-or-the-cultural-logic-of-late-capitalism [5.08.2019].

Le Sueur Marc, 1977: Theory Number Five: Anatomy of Nostalgia Film: Heritage and Methods. „Journal of Popular Film”, vol. 6.

MAJOR Małgorzata, WŁodek Patrycja, red., 2018: Pomiędzy retro a retromanią. Gdańsk: Wydawnictwo Naukowe Katedra.

Marzec Andrzej, 2015: Widmontologia. Teoria filozoficzna i praktyka artystyczna ponowoczesności. Warszawa: BęcZmiana.

McPadden „McBeardo” Mike, 2019: Teen Movie Hell. A Crucible of Coming-of-Age Comedies from Animal House to Zapped! New York: Brazillion Points.

Niemeyer Katharina, ed., 2014: Media and Nostalgia. Yearning for the Past, Present and Future. Paris: AIAA.

REYNOLDS Simon, 2018: Retromania. Jak popkultura żywi się wtasną przeszłością. Przeł. Filip Łoвodziński. Warszawa: KosmosKosmos.

SMokler Kevin, 2016: Brat Pack America: A Love Letter to '8os Teen Movies. New York-Los Angeles: Rare Bird Books.

SPREngler Christine, 2009: Screening Nostalgia. Populuxe Props and Technicolor Aesthetics in Contemporary American Film. Oxford-New York: BerghahnBooks.

SysKA Rafał, 2012: Reaganomatoretro, czyli czekając na herosa. „EKRAN-y” nr 52.

SzCZEKA£A Barbara, 2018: Nie tylko nostalgia. Fenomen retro krytycznego. W: Pomiędzy retro a retromanią. Red. Małgorzata MAJor, Patrycja WŁODEK. Gdańsk: Wydawnictwo Naukowe Katedra.

Karolina Kostyra

How to Extricate Oneself from Nostalgia

[re: P. Włodek: Kres niewinności. Obraz i upamiętnienie ery Eisenhowera w amerykańskich filmach i serialach pomiędzy reprezentacją, nostalgią a krytycznym retro]

Summary: The article discussesa book by Patrycja Włodek entitled Kres niewinności. Obraz i upamiętnienie ery Eisenhowera w amerykańskich filmach i serialach - pomiędzy reprezentacją, nostalgią a krytycznym retro [The End of Innocence: The image and remembrance of the Eisenhower era in American feature films and television series - between representation, nostalgia, and critical retro style]. The author of the article positions her publication amongst other film studies research devoted to "nostalgic cinema" and enters into dialogue with concepts put forward by Włodek. The polemical pendants and glosses centre on searching for currents, titles, and readings both supporting Włodek's considerations and transcending her interpretive framework 
relating to retro nostalgic (cinema of the 1980s) and retro classic (the most recent films and television series).

Keywords: nostalgia, retro, film studies, American cinema 